\title{
Pengintegrasian Wahana Permainan Wisata Alam Ngarai Sianok dan Wisata Buatan MiFan Water Park Padang ke dalam Materi Fisika
}

\author{
Hamdi Rifai*, Yohandri, Dewi Puspa Sari, Wenda Emafri \\ Program Studi Magister Pendidikan Fisika FMIPA, Universitas Negeri Padang, Indonesia \\ *rifai.hamdi@gmail.com
}

\begin{abstract}
Edupark is a park with a variety of rides and ecosystems that can be used as a learning tool. Ngarai Sianok, Bukittinggi is a national Geopark area that has a nature tourism vehicle and Minang Fantasy (MiFan) Padang Panjang Water Park is an artificial tourist game vehicle. In general, visitors to attractions only take advantage of the natural landscape or a vehicle to take photos, sports such as jogging, hiking, camping, family gathering or low impact outbound. Without them knowing it, there are many physics concepts in both natural and artificial games that can be used as learning resources by integrating into high school physics learning in the form of physics teaching materials or integrated in learning models. However, there are actually educa-tional values, especially the physical concepts contained in the game. The purpose of this study is to integrate Edupark Ngarai Sianok and MiFan Water Park because it remembers so many Physics concepts found in natural or artificial tourism. The process of collecting data through observation and study of literature. The results showed that Edupark physics could be integrated in learning physics according to the 2013 curriculum
\end{abstract}

Keywords : Edupark, Ngarai Sianok, MiFan Water Park Padang Panjang,

\section{PENDAHULUAN}

Salah satu konsekuensi terjadinya disrupsi dalam pendidikan adalah terciptanya perubahan paradigma pemanfaatan sumber belajar dalam pelaksanaan proses pembelajaran fisika, dimana umumnya sumber belajar fisika terjadi diruang belajar atau laboratorium saja. Kurikulum 2013 menuntut proses pembelajaran dimana terjadinya interaksi antara pendidik, peserta didik serta sumber belajar, sehingga memicu peserta didik menemukan hal-hal baru yang inovatif, dengan begitu membuat peserta didik belajar dalam kondisi yang menyenangkan sekaligus menantang dan menimbulkan motivasi sehingga peserta didik lebih berpartisipasi aktif, memberikan ruang yang cukup untuk berkreasi sesuai dengan bakat, minat dan perkembangan fisik peserta didik (Permendikbud, 2016). Salah satu bentuk perubahan paradigma terhadap sumber belajar adalah melakukan inovasi pada sumber belajar, dimana bentuk inovasi tersebut adalah dengan menjadikan objek wisata alam maupun buatan sebagai sumber belajar dalam pembelajaran fisika (Sanjaya, 2008).

Sumber belajar yang memanfaatkan objek wisata ini di sebut juga dengan educational park atau di singkat dengan edupark. Lebih lanjut edupark merupakan sebuah tempat berupa taman alami atau buatan yang memungkin untuk terjadinya proses pembelajaran dalam membantu pendidik dan peserta didik dalam menemukan fakta, merumuskan prinsip atau konsep dalam suatu pembelajaran fisika. Pembelajaran fisika melibatkan peserta didik dalam membuat prediksi, menguji konsepsi mereka dan membandingkannya dengan hasil eksperimen melalui partisipasi aktif (Berk man \& White, 2017). Dengan menjadikan edupark sebagai sumber belajar akan membuat peserta didik senang dalam belajar (Carol \& Joseph, 1969). Beberapa contoh objek wisata alami dan buatan yang dapat dijadikan edupark adalah; Geopark Ngarai Sianok (Emafri \& Hamdi, 2019), Objek Wisata MiFan Water Park Padang Panjang (Sari \& Hamdi, 2019), Janjang Siribu dan Gunung Merah Putih, Sulit Air (Gusweri \& Hamdi, 2019) Geopark Harau, Kabupaten Lima Puluh Kota (Yulia \& Hamdi, 2019) Air Panas Semurup, Kerinci (Veno \& Hamdi, 2019) dan taman sekolah (Afrinaldi \& Hamdi, 2019).

Biasanya pengunjung objek wisata hanya memanfaatkan keindahan alam dan wahana untuk mengambil mengambil foto, olah raga seperti jogging, hicking, camping, family gathering ataupun low impact outbond. Tanpa mereka sadari, pada wahana permainan alam maupun 
buatan tersebut banyak terdapat konsep fisika. Pemanfaatan edupark melalui objek wisata alam dan buatan sebagai sumber belajar merupakan bahwa adanya perubahan mindset terhadap fisika yang menyatakan bahwa fisika adalah mata pelajaran yang membosankan, sulit, dan monoton dan kaku, padahal sebaliknya pembelajaran fisika dapat terjadi pada dalam konteks yang menyenangkan. Prinsip pendidikan merupakan salah satu yang harus dimanfaatkan dan dikembangkan dari Geopark Ngarai Sianok. Pengembangan itu bisa dilakukan seperti inovasi pembelajaran di alam sebagai bentuk variasi pembelajaran dan penyegaran serta dengannya membuat seseorang terutama pelajar bisa belajar sambil berekreasi (Ismail, 2014).

Agar wawasan siswa terhadap hubungan pembelajaran fisika dengan wahana-wahana bermain terbentuk maka perlu di buatkan suatu bahan ajar dengan menggunakan teknik tertentu. Oleh sebab itu penelitian ini bertujuan untuk mengintegrasikan konsep-konsep fisika yang ada pada pada wahana alam permainan si Geopark Ngarai Sianok dan Mifan Water Park Padang Panjang ke dalam pembelajaran fisika.

\section{METODE PENELITIAN}

Ngarai Sianok adalah kawasan Geopark nasional. tujuan pengembangan geopark pun lebih ditingkatkan lagi, tidak sekedar melindungi warisan geologi, namun juga mengambil manfaat, menggali, menghargai dan mengembangkan warisan geologi tersebut (Dowling, 2011). Ngarai Sianok berada di provinsi Sumatera Barat, Indonesia. Peta Ngarai Sianok dapat diamati pada peta Gambar 1. Geopark Ngarai sianok adalah destinasi wisata yang memiliki panorama yang indah dan unik. Wahana permainan alami yang terdapat di kawasan ini adalah situs sejarah masa penjajahan Jepang yaitu Lobang Jepang, Jembatan Hati Guguak Tabek Sarojo, Tabek Taruko, Sungai Batang Sianok, Wisata Rumah Inyiak, Wisata Janjang Seribu, dan lain-lain (Wenda \& Hamdi, 2019). Ngarai Sianok terletak di Kota Bukittinggi Kabupaten Agam Provinsi Sumatra Barat. Keunikan geologi dari Ngarai Sianok yaitu terdapatnya patahan besar dan dikenal dengan Sesar Semangko (Putri, 2015).

Minang Fantasi(MiFan) Water Park terletak di Padang Panjang, Sumatera Barat (Gambar 1) merupakan taman air yang memiliki beragam wahana taman air (water park) dan taman kering (dry park). Water park terdiri dari kolam renang anak-anak (kiddy pool), kolam dengan tumpahan air dari ember raksasa (giant water bucket spills), lazy river, papan luncur terbuka, dan papan luncur berderet (multi ricer slide). Dry park terdiri dari flying fox, bumper boat, bumper carcarousel, dan lainnya. Tidak hanya itu, MiFan juga menyediakan fasilitas lainnya, seperti ruang billiard, futsal, sauna, arena berkemah, bioskop 4 dimensi, dan cottage.

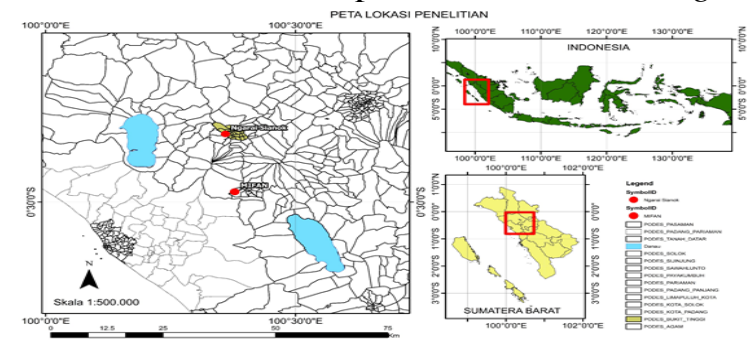

Gambar 1. Peta kawasan Geopark

Nasional Ngarai Sianok, Bukittinggi dan MiFan Water Park Padang Panjang, Sumatera Barat, dimana posisi Ngarai Sianok dan Mifan Water Park di tandai dengan titik merah.

Penelitian ini menggunakan Metode deskriptif dimana analisis deskriptif dilakukan dengan cara mengintegrasikan Geopark Nasional Ngarai Sianok dan MiFan Water Park ke dalam konsep-konsep fisika dengan cara pengumpulan data yang dilakukan melalui observasi dan studi literatur. Dalam proses observasi, digunakan suatu instrument observasi yang sudah di validasi terlebih dahulu oleh para ahli. Hubungan antara studi literatur serta observasi dengan konsep fisika dilakukan menggunakan Concepts Fitting Technique (Rifai, Hamdi, A. Fauzi \& Y Amir, 2014).

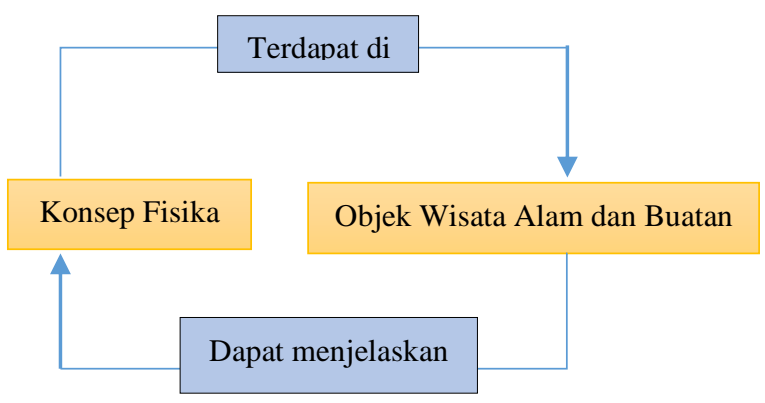

Gambar 2. Skema pemanfaatan objek wisata sebagai pembelajaran fisika.

Gambar 2 menunjukkan adanya keterkaitan konsep-konsep fisika dengan objek wisata baik alam dan buatan seperti pada bentangan geopark Ngarai sianok dan objek wisata MiFan Water 
Park. MiFan Water Park memiliki berbagai bentuk desain wahana, seperti seluncuran lurus dan berkelok. Seluncuran tersebut di aliri dengan air dan jika pengunjung ingin berseluncur ada ketentuan untuk memakai matras untuk keamanan. Debit air yang mengalir pada seluncuran juga diatur besarnya serta kemiringan seluncuran dibuat sedemikian rupa. Desain wahana yang demikian serta aturan penggunaaan wahana dapat dijelaskan dengan konsep-konsep fisika. Jika dikaitkan dengan pembelajaran fisika, pendidik dan peserta didik dapat menjadikan wahana tersebut untuk menjelaskan konsepkonsep fisika karena wahana tersebut bekerja berdasarkan konsep-konsep fisika. Hasil penelitian berupa integrasi antara edupark dengan konsep fisika yang sesuai dengan kurikulum 2013 ditampilkan dalam bentuk matrik hubungan antara objek-objek fisika dengan konsep-konsep fisika

\section{HASIL DAN PEMBAHASAN}

Pemanfaatan objek wisata alam dan buatan sebagai edupark dalam proses pembelajaran dengan mengintegrasikan wahana yang ada pada edupark tersebut pada materimateri fisika yang terdapat pada kompetensi dasar. Analisis terhadap lingkungan Geopark Ngarai Sianok dan wahana-wahana basah yang terdapat pada objek wisata MiFan Water Park dilakukan untuk mengintegrasikan lingkungan geopark dan wahana tersebut ke dalam pembelajaran fisika. Hal ini dilakukan untuk menemukan prinsip-prinsip atau konsep-konsep fisika. Bentuk integrasi antara kompetensi dasar dengan wahana geopark diuraikan pada Tabel 1 dan Tabel 2.

Tabel 1. Analisis Keterkaitan Objek Wisata Geopark Ngarai Sianok dengan Konsep Fisika:

\begin{tabular}{|c|c|c|}
\hline No. & Nama Objek & Konsep Fisika \\
\hline & $\begin{array}{l}\text { Wisata "Jembatan Hati" Guguak } \\
\text { Tabek Sarojo }\end{array}$ & $\begin{array}{l}\text { Kesetimbangan benda tegar. } \\
\text { - Momen gaya } \\
\text { - Momen inersia } \\
\text { - Keseimbangan benda tegar } \\
\text { - Titik berat } \\
\text { - Hukum kekekalan momentum sudut pada gerak rotasi } \\
\text { Jembatan bermaterial besi baja ini, jadi penaut "dua } \\
\text { hati" antara jorong: Guguak Randah dan Guguak } \\
\text { Tinggi, Kenagarian Guguak Tabek Sarojo, IV Koto, } \\
\text { Agam . Dipisahkan bentangan Ngarai Sianok yang di } \\
\text { bawahnya mengalir Batang Sianok .Panjang jembatan } \\
125 \text { meter dan ketinggian } 150 \text { meter dari dasar ngarai. }\end{array}$ \\
\hline 2. & $\begin{array}{l}\text { Wisata "Lobang Jepang" Situs } \\
\text { sejarah masa penjajahan Jepang }\end{array}$ & $\begin{array}{l}\text { Elastisitas. } \\
\text { - Elastisitas Bahan } \\
\text { Gerbang Lobang Jepang di Ngarai Sianok berupa } \\
\text { lengkungan setengah lingkaran. Batu-batu yang disusun } \\
\text { melengkung mengalami tegangan tekan (batu-batu } \\
\text { saling berdempetan) sehingga dapat menahan beban } \\
\text { berat yang ada di atasnya. Ingat ya, batu sangat kuat } \\
\text { terhadap tekanan }\end{array}$ \\
\hline 3. & $\begin{array}{l}\text { Tabek Taruko adalah kolam tenang } \\
\text { di Café Taruko }\end{array}$ & $\begin{array}{l}\text { Fluida Statis. } \\
\text { - Hukum utama hidrostatis } \\
\text { - Tekanan Hidrostatis } \\
\text { - Hukum Pascal } \\
\text { - Hukum Archimedes } \\
\text { - Meniskus } \\
\text { - Gejala kapilaritas }\end{array}$ \\
\hline
\end{tabular}




\begin{tabular}{|c|c|c|}
\hline No. & Nama Objek & Konsep Fisika \\
\hline & & $\begin{array}{l}\text { Viskositas dan Hukum Stokes } \\
\text { Macam-macam fluida yang terdapat di Ngarai Sianok } \\
\text { adalah, udara, dan airnya. Tabek Taruko ini adalah } \\
\text { contoh fluida statis. }\end{array}$ \\
\hline 4. & Wisata "Sungai Batang Sianok" & $\begin{array}{l}\text { Fluida Dinamis. } \\
\text { - Fluida ideal } \\
\text { - Azas kontinuitas } \\
\text { - Azas Bernoulli } \\
\text { Di sepanjang dasar Ngarai Sianok mengalir sebuah } \\
\text { sungai yang bernama Batang Sianok. Sungai adalah } \\
\text { contoh fluida dinamis }\end{array}$ \\
\hline
\end{tabular}

Integrasi destinasi wisata di Geopark Nasional Ngarai Sianok pada Kompetensi Dasar Mata Pelajaran Fisika kelas XI semester 1 Kurikulum 2013 dapat dilihat pada Tabel 2. Kompetensi Pengetahuan dengan kode 3, dan Kompetensi Keterampilan dengan kode 4 . Setiap
Kompetensi Dasar pengetahuan dan keterampilan diturunkan menjadi Indikator Pencapaian Kompetensi (IPK) dan dijabarkan ke kegiatan pembelajaran yang dikaitkan dengan pemanfaatan Geopark Nasional Ngarai Sianok sebagai Edupark Fisika.

Tabel 2. Keterkaitan Kompetensi Dasar dengan Geopark Ngarai Sianok pada Pembelajaran Fisika Kelas XI semester 1 Kurikulum 2013.

\begin{tabular}{|c|c|c|}
\hline \multicolumn{2}{|r|}{ Kompetensi Dasar } & \multirow{2}{*}{$\begin{array}{l}\text { Pengintegrasian Geopark dalam } \\
\text { Pembelajaran } \\
\text { - Menghubungkan materi keseimbangan dan } \\
\text { dinamika rotasi dengan Geopark Ngarai } \\
\text { Sianok (Kesetimbangan Jembatan yang ada } \\
\text { di Ngarai Sianok) }\end{array}$} \\
\hline 3.1 & $\begin{array}{l}\text { Menerapkan konsep torsi, momen inersia, } \\
\text { titik berat, dan momentum sudut pada } \\
\text { benda tegar (statis dan dinamis) dalam } \\
\text { kehidupan sehari-hari }\end{array}$ & \\
\hline 4.1 & $\begin{array}{l}\text { Membuat karya yang menerapkan konsep } \\
\text { titik berat dan keseimbangan benda tegar. }\end{array}$ & \\
\hline 3.2 & $\begin{array}{l}\text { Menganalisis sifat elastisitas bahan dalam } \\
\text { kehidupan sehari-hari }\end{array}$ & $\begin{array}{l}\text { - Menghubungkan materi elastisitas dengan } \\
\text { Geopark Ngarai Sianok (Gerbang Lobang } \\
\text { Jepang di Ngarai Sianok berupa } \\
\text { lengkungan setengah lingkaran batu-batu } \\
\text { yang disusun melengkung } \\
\text { mengalami tegangan tekan (batu-batu } \\
\text { saling berdempetan) sehingga dapat } \\
\text { menahan beban berat yang ada di atasnya. }\end{array}$ \\
\hline 4.2 & $\begin{array}{l}\text { Melakukan percobaan tentang sifat } \\
\text { elastisitas suatu bahan berikut presentasi } \\
\text { hasil dan makna fisisnya }\end{array}$ & \\
\hline 3.3 & $\begin{array}{l}\text { Menerapkan hukum-hukum fluida statik } \\
\text { dalam kehidupan sehari-hari. }\end{array}$ & $\begin{array}{l}\text { - Menghubungkan materi fluida statis } \\
\text { dengan Ngarai Sianok (Macam-macam } \\
\text { fluida yang terdapat di Ngarai Sianok } \\
\text { adalah, udara, tanah dan airnya) }\end{array}$ \\
\hline 4.3 & $\begin{array}{l}\text { Merencanakan dan melakukan percobaan } \\
\text { yang memanfaatkan sifat-sifat fluida statis, }\end{array}$ & \\
\hline
\end{tabular}




\begin{tabular}{cc}
\hline Kompetensi Dasar & $\begin{array}{c}\text { Pengintegrasian Geopark dalam } \\
\text { Pembelajaran }\end{array}$ \\
\hline
\end{tabular}

berikut presentasi hasil dan makna fisisnya

3.4 Menerapkan prinsip fluida dinamik dalam teknologi

4.4 Membuat dan menguji proyek sederhana yang menerapkan prinsip dinamika fluida, dan makna fisisnya.
3.5 Menganalisis pengaruh kalor dan perpindahan kalor yang meliputi karakteristik termal suatu bahan, kapasitas, dan konduktivitas kalor pada kehidupan sehari-hari

4.5 Merencanakan dan melakukan percobaan tentang karakteristik termal suatu bahan, terutama terkait dengan kapasitas dan konduktivitas kalor, beserta presentasi hasil dan makna fisisnya
- Menghubungkan materi fluida dinamis dengan Geopark Ngarai Sianok (Aliran air batang Sianok).
- Menghubungkan materi suhu dan kalor dengan Geopark Ngarai Sianok (Pagi hari di Ngarai sianok suhu tubuh akan lebih tinggi dari pada suhu udara Ngarai Sianok. Sehingga kalor akan berpindah dari tubuh ke lingkungan. Sehingga tubuh merasa kedinginan. Sebelum suhu tubuh pindah ke lingkungan maka dipasanglah sweater sebagai isolator. Perpindahan kalor dari tubuh ke lingkungan terhalang oleh Sweater)

3.6 Memahami teori kinetik gas dan - Mengamati proses pemanasan air misalnya karakteristik gas pada ruang tertutup pada ketel uap atau melalui tayangan video dan animasi tentang perilaku gas

4.6 Mempresentasi-kan laporan hasil pemikiran

- Menghubungkan materi teori kinetik gas tentang teori kinetik gas, dan makna dengan Ngarai Sianok. fisisnya

3.7 Menganali perubahan keadaan gas ideal dengan menerapkan Hukum

- Meninjau suhu pada Ngarai Sianok Termodinamika sekaitan dengan konsep termodinamika

4.7 Membuat karya/model penerapan Hukum I dan II Termodinamika dan makna fisisnya

Analisis terhadap kompetensi dasar (KD) ini dipakai untuk melihat kesesuaian materi dengan perangkat pembelajaran fisika berbasis PjBL serta untuk merumuskan indikator-indikator pencapaian pembelajaran yang menjadi pedoman dalam pengembangan perangkat pembelajaran fisika berbasis $\mathrm{PjBL}$ untuk kelas XI MIPA semester I. Analisis ini ditujukan agar tercapainya Indikator Pencapaian
Kompetensi pembelajaran yakni terkait permasalahan fisika yang terdapat di edupark Ngarai Sianok.

Selanjutnya diuraikan hasil analisis wahana-wahana yang terdapat pada MiFan Water Park Padang Panjang terhadap konsep fisika seperti pada Tabel 3. 
Tabel 3. Keterkaitan Kompetensi Dasar dengan Objek Wisata MiFan Water Park Padang Panjang pada Pembelajaran Fisika kelas XI semester 1 Kurikulum 2013.

\begin{tabular}{cll}
\hline No. & Nama Wahana & \\
\hline 1. & Kolam Ombak & $\begin{array}{l}\text { Jarak, Waktu, Kecepatan, Percepatan, Energi Kinetik, Usaha, } \\
\text { Perubahan Energi Kinetik, Gelombang }\end{array}$ \\
\hline 2. & Menara Seluncur & $\begin{array}{l}\text { Ketinggian, Kecepatan Sudut, Percepatan Sudut, Gaya } \\
\text { Sentripetal, Gaya Sentrifugal, Gaya Gesekan }\end{array}$ \\
\hline 3. & Ember Tumpah & $\begin{array}{l}\text { Ketinggian, Usaha, Energi Kinetik, Energi Potensial, Hukum } \\
\text { Kekekalan energi Mekanik, Debit, Gerak Parabola }\end{array}$ \\
\hline 4. & Kolam Arus & Jarak, Perpindahan, Kecepatan, Percepatan, Energi Kinetik, \\
& & Debit, Tekanan, \\
\hline 5. & Kolam Semi Olimpic & Jarak, Kecepatan, Percepatan, Tekanan Hidrostatik, Hukum- \\
& & hukum Newton, Hukum Archimedes, Tegangan Permukaan, \\
& & Gejala-gejala Gelombang, Indek Bias, Massa Jenis. Hukum \\
& & Pascall, Elastisitas, Elektrolit \\
\hline 6. & Kolam Khusus Wanita & Jarak, Kecepatan, Percepatan, Tekanan Hidrostatik, Hukum \\
& & Archimedes, Hukum I Newton, Hukum II Newton, Hukum III \\
& & Tegangan Permukaan, Gejala-gejala Gelombang, Indek Bias, \\
& & Massa Jenis, Hukum Pascall, Elektrolit \\
\hline 7. & Kolam Anak & Jarak, Kecepatan, Percepatan, Tekanan Hidrostatik, Hukum \\
& & Archimedes, Gejala-gejala Gelombang, Indeks bias, Massa \\
& & Jenis, Elektrolit \\
\hline 8. & Kolam Air Hangat & Suhu, Kalor, Perpindahan Kalor, Massa Jenis, Elektrolit \\
\hline 9. & Menara Seluncur 4 & Jarak, Kecepatan, Percepatan, Gaya Gesekan \\
\hline & &
\end{tabular}

Penjelasan lebih lanjut mengenai dan perubahan energi, hukum kekekalan energi, pengintegrasian wahana objek wisata MiFan serta penerapannya dalam peristiwa sehari-hari Water Park kedalam materi fisika pada konsep dijelaskan pad Tabel 4. energi, usaha (kerja), hubungan usaha (kerja)

Tabel 4. Keterkaitan kompetensi dasar dengan Geopark Mifan Padang Panjang pada pembelajaran Fisika kelas XI semester 1 Kurikulum 2013

\begin{tabular}{lll}
\hline No & Nama Wahana & Konsep Fisika yang akan Dijelaskan \\
\hline 1. & Edupark Kolam Semi Olimpic & $\begin{array}{l}\text { Perubahan Energi Kinetik dengan Usaha, menjelaskan } \\
\text { konsep Usaha, usaha oleh berbagai gaya. }\end{array}$ \\
\hline 2. & Kolam Ombak & $\begin{array}{l}\text { Faktor-faktor yang mempengaruhi besar kecilnya energi } \\
\text { kinetik suatu benda }\end{array}$ \\
\hline 3. & Menara Seluncur 4 & $\begin{array}{l}\text { Menjelaskan konsep usaha yang membentuk sudut } \\
\text { terhaap perpindahan, usaha oleh gaya gesekan, }\end{array}$ \\
\hline
\end{tabular}




\begin{tabular}{lll}
\hline No & Nama Wahana & Konsep Fisika yang akan Dijelaskan \\
\hline & & menentukan koefesien gesekan bidang seluncuran \\
\hline 4. & Edupark Menara Seluncur & Hubungan Usaha dengan Perubahan Energi Potensial. \\
\hline 5. & Edupark Menara Seluncur & Menyelidiki Hubungan Usaha dan Waktu
\end{tabular}

Setelah dilakukan analisis wahana MiFan Water Park dengan konsep-konsep yang terdapat pada materi Usaha dan Energi, maka dilaksanakan pembelajaran dengan melak sanakan salah satu model pembelajaran dengan mengintegrasikan edupark MiFan Water Park Padang Padang sebagai sumber belajar, dalam hal ini menggunakan model pembelajaran discovery learning. Sebelum melaksanakan pembelajaran peserta didik dibagi dalam beberapa kelompok dan tiap kelompok beranggotakan 4-5 orang tiap kelompok. Salah seorang peserta didik melakukan aktivitas yang disesuaikan dengan panduan berupa lab edupark yang ada pada buku ajar edupark MiFan Water Park, sementara peserta didik lain mengamati aktivitas yang dilakukan oleh peserta didik yang ditunjuk. Tahapan pertama ini merupakan sintaks pertama dari discovery learning yaitu stimulasi. Tahapan kedua adalah mengidentifikasi masalah, peserta didik dalam kelompok mengajukan pertanyaan-pertanyaan sebanyak mungkin dari hasil pengamatan atau aktivitas yang telah dilakukan pada lab edupark terkait dengan konsep yang sedang dibahas, kemudian merumuskan hipotesis terhadap pertanyaan-pertanyaan yang telah terkumpul. Tahapan ketiga adalah peserta didik melakukan pengumpulan data. Pengambilan data dilakukan di edupark MiFan Water Park. Tahapan keempat adalah pengolahan data kemudian dilanjutkan dengan verifikasi yaitu peserta didik mendiskusikan secara klasikal topik yang dibahas dan diambil kesimpulan.

Berdasarkan sintak model pembelajaran discovery learning dapat diungkapkan bahwa Edupark MiFan Water Park dapat diintegrasikan pada pelaksanaan sintaks tersebut. Kelebihan Edupark dalam pelaksanaan terhadap model pembelajaran adalah, peserta didik terlibat sebagai objek pada tahap stimulus, yang semula peserta didik hanya melihat video, gambar atau narasi saja, disamping itu edupark MiFan Water Park dapat dijadikan sarana atau sumber belajar dalam proses pembelajaran fisika. Kelebihan lainnya dengan menggunakan edupark MiFan Water Park ini adalah pendidik dapat melaksanakan penilaian sikap dan keterampilan seperti yang dituntut pada Kurikulum 2013.

Dengan demikian setelah pembelajaran fisika melalui edupark Ngarai Sianok dan edupark MiFan Water Park diharapkan terjadinya perubahan pada peserta didik dari tiga aspek yaitu aspek sikap, pengetahuan dan keterampilan. Perubahan tersebut terjadi melalui proses interaksi secara langsung dengan sumber belajar yang telah dirancang melalui proses dan pendekatan ilmiah.

\section{KESIMPULAN}

Pemilihan objek wisata alami dan buatan sebagai edupark dalam pembelajaran fisika disebabkan pada objek wisata tersebut banyak memuat fakta-fakta, prinsip-prinsip serta konsep-konsep yang dibutuhkan dalam pembelajaran fisika. Dari hasil pengintegrasian diketahui bahwa objek wisata alami (Ngarai Sianok) dan buatan (MiFan Water Park Padang Panjang) dapat dijadikan sebagai sumber belajar dan sebagai sarana dalam menggunakan tahapan-tahapan dari model pembelajaran seperti pada model discovery learning

\section{DAFTAR PUSTAKA}

Afrinaldi., \& Hamdi Rifai. (2019). Evaluation of Garden Functions of SMAN 2 Lubuk Basung as Science Based Education Park. J. Phys.: 1185012126.

Anggara., Veno Julian., \& Hamdi Rifai. (2019). The Preliminary Analysis of Edupark Learning device of temperature and heat physics of Air Panas Semurup Kerinci District. J.Phys.: Ser. 1185012095.

Berkman, B. Y. R. M., \& White, B. P. (2017). Fulfilling Cleveland State University's Roles as Educator and Anchor Through an "Education Park" Model. Journal on 
Anchor Institutions and Communities. 1, 19.

Carrol. M Joseph. (1969). The Education Park, The Task Force on Educational Park, Di visin of Planning Innovation and Research Public schools of the Distric of Columbia

Dowling, R. K. (2011). Geotourism's Global Growth. Geoheritage.

Emafri., Wenda., \& Hamdi Rifai. (2019). Ngarai Sianok as Physis Education's Edupark. J Phys: Conf.Ser.1185012123

Gusweri., Siska., \& Hamdi Rifai. (2019). Preliminary Nalysis Based Instructional Materials Edupark Learning Natural Science Method of Travel Work in Janjang Seribu And Merah Putih Mountain Sulit Air. J.Phys,: Conf. Ser.1185 012094

Ismail, N. K. (2014). Evaluasi Fungsi Taman Kampus Edu Park Universitas Muhammadiyah Surakarta Sebagai Open Space Kampus. 14(2), 269-283.

Permendikbud (2016) Standar Proses Pendidikan Dasar dan Menengah No. 22

Putri, R. K. (2015). Pengembangan Pariwisata Oleh Dinas Kebudayaan Dan Pariwisata
(Disbudpar) Kota Bukittinggi Untuk Meningkatkan Pendapatan Asli Daerah (PAD), Thesis, Universitas Andalas.

Rifai Hamdi., Fauzi., \& Amir. 2014. Energy Saving Character Integrated to Physics By Using Concepts Fitting Technique. Prosiding Seminar Nasional dan Rapat Tahunan Bidang MIPA 2014. Bogor: 9-11 Mei 2014. Hal. 269-277.

Sari, D. P., \& Hamdi Rifai. (2019) Preliminary analysis of Edupark fluid learning tool in MiFan Water Park Padang Panjang City IOP Conf. Series: Journal of Physics: Conf. Series 1185 (2019) 012091

Kemendikbud, 2017, Silabus Mata Pelajaran SMA /MA Mata Pelajaran Fisika.

Sanjaya, W., (2008), Strategi Pembelajaran Berorientasi Proses Pendidikan, Jakarta: Macanan Jaya cemerlang

Yulia \& Hamdi Rifai. (2019). Preliminary Study of Edupark energi in geopark Harau Lima Puluh Kota Regency.J.Phys.: Conf. Ser 1185012098 